\title{
Breast cancer cell lines carry cell line-specific genomic alterations that are distinct from aberrations in breast cancer tissues: Comparison of the CGH profiles between cancer cell lines and primary cancer tissues
}

Katumi Tsuji ${ }^{1}$, Shigeto Kawauchi ${ }^{1}$, Soichiro Saito ${ }^{2}$, Tomoko Furuya $^{1}$, Kenzo Ikemoto ${ }^{1}$, Motonao Nakao', Shigeru Yamamoto ${ }^{3}$, Masaaki Oka ${ }^{3}$, Takashi Hirano ${ }^{2}$, Kohsuke Sasaki ${ }^{13^{*}}$

\begin{abstract}
Background: Cell lines are commonly used in various kinds of biomedical research in the world. However, it remains uncertain whether genomic alterations existing in primary tumor tissues are represented in cell lines and whether cell lines carry cell line-specific genomic alterations. This study was performed to answer these questions.

Methods: Array-based comparative genomic hybridization (CGH) was employed with 4030 bacterial artificial chromosomes (BACs) that cover the genome at 1.0 megabase resolution to analyze DNA copy number aberrations (DCNAs) in 35 primary breast tumors and 24 breast cancer cell lines. DCNAs were compared between these two groups. A tissue microdissection technique was applied to primary tumor tissues to reduce the contamination of samples by normal tissue components.

Results: The average number of BAC clones with DCNAs was 1832 (45.3\% of spotted clones) and 971 (24.9\%) for cell lines and primary tumor tissues, respectively. Gains of $1 q$ and $8 q$ and losses of $8 p, 11 q, 16 q$ and $17 p$ were detected in $>50 \%$ of primary cancer tissues. These aberrations were also frequently detected in cell lines. In addition to these alterations, the cell lines showed recurrent genomic alterations including gains of 5p14-15, 20q11 and 20q13 and losses of 4p13-p16, 18q12, 18q21, Xq21.1 and Xq26-q28 that were barely detected in tumor tissue specimens. These are considered to be cell line-specific DCNAs. The frequency of the HER2 amplification was high in both cell lines and tumor tissues, but it was statistically different between cell lines and primary tumors $(P=$ $0.012) ; 41.3 \pm 29.9 \%$ for the cell lines and $15.9 \pm 18.6 \%$ for the tissue specimens.

Conclusions: Established cell lines carry cell lines-specific DCNAs together with recurrent aberrations detected in primary tumor tissues. It must therefore be emphasized that cell lines do not always represent the genotypes of parental tumor tissues.
\end{abstract}

\section{Background}

Cancer cell lines are routinely used for various kinds of biomedical research under the assumption that cell lines reflect the genotypic and phenotypic characteristics of primary tumor tissues. However, such cell lines do not always faithfully represent genomic alterations and gene

\footnotetext{
* Correspondence: kohasuke@yamaguchi-u.ac.jp
${ }^{1}$ Department of Pathology, Yamaguchi University Graduate School of

* Correspondence: kohasuke@yamaguchi-u.ac.jp
'Department of Pathology, Yamaguchi University Graduate School of Medicine, Ube 755-8505, Japan
}

expression observed in tumor tissue specimens [1-4], and therefore the use of cell lines may lead to erroneous conclusions in some instances. In order to avoid erroneous conclusions in experiments using the cell lines, first of all, it is important to clarify the extent of similarities and differences in genomic aberrations between cancer cell lines and primary cancer tissues.

According to the commonly accepted model for cancer development, somatic mutations accumulate in a 
cell in the process of tumorigenesis. In clinically overt cancers, not only a large number of genomic aberrations are detected but also genomic instability successively yields genomic alterations in a cancer cell. This theory explains why the number of genomic aberrations is greater in advanced cancers than in early cancers [5-8]. The established cell lines also undergo genomic changes with multiple passages in culture [9-11]. Some of the genomic alterations detected in the cell lines are considered as a result of selective pressure to adapt to the culture conditions, while others may be just incidental $[12,13]$. This theory raises an additional question in regard to whether there are genomic aberrations specific for cell lines, or in vitro-specific genomic aberrations. In this context, it is crucial to distinguish genomic aberrations in tumor tissues from the secondary changes with cultivation. The differentiation between these aberrations is practically difficult, because available data on difference in the genomic changes between cell lines and tumor tissue specimens are very limited at present $[13,14]$. The comparison of genomic profiles obtained from cell lines with those from primary tumor tissues is one of the best ways to determine the difference in genomic aberrations between cell lines and primary tumor tissues and to identify recurrent celll lines-specific genomic aberrations.

This study examined the DNA copy number aberrations (DCNAs) of 24 breast cancer cell lines and 35 primary breast cancer tissues using array-based comparative genomic hybridization (aCGH). The present paper showed that the breast cancer cell lines preserved genomic alterations detected in primary cancer tissue specimens and that the cell lines concurrently carried secondary genomic alterations. Some of the secondary genomic alterations were recurrent and cell line-specific.

\section{Methods}

\section{Cell lines}

This study used 24 cell lines established from human breast cancer as follows: AU565, HCC2218, T-47D, HCC1954, MDAMB361, UACC812, UACC893, BT474, SKBR3, HCC38, HCC1008, ZR-75-30, HCC1937, MDAMB468, HCC1428, ZR-75-1, MCF7, MDAMB231, MDAMB435S (possibly derived from melanoma), BT483, HCC1806, Hs578T, MDAMB175VII and MDAMB415. These cell lines were purchased from American type Culture Collection (Manassas, VA). The original histology of these cell lines was as follows: 6 adenocarcinomas, 10 invasive ductal carcinomas, and 8 unknown tumors [15].

\section{Tumor specimen}

Thirty-five primary breast cancers that were histologically classified as invasive duct carcinoma were used. All tumors were considered to be sporadic. The average age of patients was 57.6 years, ranging from 31 to 75 years old. In this series, the expression of estrogen and progesterone receptors was positive for 27 (77.1\% of tumors) and 19 (54.3\%) tumors, respectively. The Institutional Review Board for Human Use Yamaguchi University Graduate School of Medicine approved the study protocol and informed consent for this study was obtained from all patients. A tissue microdissection technique was used to reduce the contamination of samples by normal tissue components for array CGH analyses, as previously described [16]. As a result, the normal cell contamination of samples was usually reduced to less than $10 \%$.

\section{Genomic DNA}

High-molecular-weight DNA was extracted from each tumor specimen with a DNA extraction kit (SepaGene, Sankojyunyaku Co., Tokyo, Japan) according to the manufacturer's instructions as previously described [17-21].

\section{Array-based CGH}

The BAC DNA array used in this study consists of 4030 human bacterial artificial chromosome (BAC) clones, including 356 cancer-related genes, which are spaced approximately $1.0 \mathrm{Mb}$ across the whole genome (MacroGen, Inc., Seoul, Korea). BAC chip information including data of end-sequenced BAC clones is available on the following websites: http://www.macrogen.co.kr/eng/biochip/ karyo_summary.jsp. The experiments were performed as previously described [19-22]. Briefly, tumor DNA and gender-matched reference DNA (Promega, Madison, WI) were labeled with Cy5 and Cy3-dCTP (PerkinElmer Life Science, Inc.), respectively, with a random primer labeling kit (BioPrime ${ }^{\circ}$ DNA Labeling System, Invitrogen $\left.{ }^{\mathrm{Tm}}\right)$. For hybridization, labeled DNA was mixed with Cot-1 DNA (50 mg, Gibco BRL, Gaithersburg, MD) and ethanol precipitated. The precipitated DNA was dissolved in $40 \mu \mathrm{l}$ of hybridization mix. The probe mixture was denatured at $75^{\circ} \mathrm{C}$ for $5 \mathrm{~min}$ and incubated at $37^{\circ} \mathrm{C}$ for $60 \mathrm{~min}$ for blocking of repetitive sequences. Arrays were prehybridized with salmon sperm DNA to reduce nonspecific background staining. The probe mixture was applied to the array. The arrays were placed in a moist chamber at $37^{\circ} \mathrm{C}$ for $72 \mathrm{hr}$ for hybridization. The array slides were washed 2 times in $2 \times$ standard saline citrate $(2 \times \mathrm{SSC})$, $50 \%$ formamide, $\mathrm{pH} 7.0$, at $45^{\circ} \mathrm{C}$. The array slides were washed in phosphate buffer with $0.1 \% \mathrm{NP}-40, \mathrm{pH} 8.0$, once in $2 \times \mathrm{SCC}$ at room temperature.

\section{Imaging and analysis}

After hybridization, the slides were scanned on a GenePix 4000A scanner (Axon Instruments, Union City, CA) 
and the 16-bit TIFF images captured using GenePix Pro 5.0 software. Fluorescence images were analyzed with the MAC Viewer ${ }^{\mathrm{rm}}$ software program (Macrogen Inc.) optimized for analysis of the array as previously reported [20-22]. Fluorescence spots were defined with the automatic grid feature and adjusted manually. Then the ratio of the red/green channel of each clone was calculated and converted to a $\log _{2}$ ratio. The clones with $\log _{2}$ ratios that exceed least than \pm 0.25 were considered gain and loss of the copy number. We defined the $\log _{2}$ ratio $>1.0$ as amplifications. A part of the cell line CGH data has been previously reported [23].

\section{Statistical analysis}

The clone-by-clone comparison of the copy number was made between the cell lines and tumor tissue specimens. The differences in the prevalence of common gains and losses between cell lines and tumor tissues were determined with the chi-square test. Differences in the total number of changes and frequency were tested by Student $t$-test. In this study, the Bonferroni correction was made to adjust the p-value. A difference was considered to be significant when the P-value was less than $1.25 \times$ $10^{-5}(0.05 / 4030)$.

\section{Results}

CGH profiles were considerably different between the cell lines and tumor tissue specimens (Figure 1), and the array data reported in this manuscript are available on the following websites: http://cibex.nig.ac.jp/cibex2/ ExperimentMiame.do?queryExperimentalDesignAccession $=$ CBX105. The number of DCNAs was more in the cell lines than in the tissue specimens as a general trend. The average number of copy number gains and losses were $651.7 \pm 148.8$ (standard deviation) and $1180.7 \pm 433.8$, respectively in cell lines, while they were $424.2 \pm 215.9$ and $548.0 \pm 324.7$ in the tumor tissue specimens (Figure 2). However, no statistical difference was found between these two groups. The average number of clones with DNA amplification was statistically different between the cell lines and the tissue specimens ( $\mathrm{P}=$ 0.012 ), $41.3 \pm 29.9$ for the cell lines and $15.9 \pm 18.6$ for the tissue specimens (Figure 2).

DCNAs were frequently detected on the all chromosomes in the cell lines, but inter-regional differences in the frequency were apparent. DCNAs detected In $>50 \%$ of the cell lines were as follows: clones with copy number gains and losses were detected at $1 \mathrm{q}, 5 \mathrm{p}, 8 \mathrm{q}$ and $20 \mathrm{q}$ and at $1 \mathrm{p}, 3 \mathrm{p}, 4 \mathrm{p}, 6 \mathrm{p}, 8 \mathrm{p}, 9 \mathrm{p}, 10 \mathrm{q}, 11 \mathrm{p}, 13 \mathrm{q}, 15 \mathrm{q}, 17 \mathrm{p}$, $18 \mathrm{q}$ and $\mathrm{X}$, respectively (Figure $1 \mathrm{a}$ ). DCNAs detected in $>50 \%$ of the tissue specimens were as follows: gains of $1 \mathrm{q}$ and $8 \mathrm{q}$, and losses of $8 \mathrm{p} \mathrm{11q,16q}$ and $17 \mathrm{p}$ were detected (Figure 1b). There were DCNAs shared by the cell lines and tumor tissue specimens and recurrent
DCNAs in the tissue specimens were generally frequent in the cell lines. The copy number gains of $1 \mathrm{q}$ and $8 \mathrm{q}$ were frequent in both the cell lines and tissue specimens (Table 1). In particular, the gain of 1q44 was detected in $13(54.3 \%)$ of 24 cell lines and in 19 (54.3\%) of 35 tissue specimens. The gain of $8 \mathrm{q} 22.1$ was detected in 15 $(62.5 \%)$ of the cell lines and in $22(62.9 \%)$ of the tissue specimens. The copy number losses of $11 \mathrm{q}$ and $17 \mathrm{p}$ were frequent in both the cell lines and the tissue specimens. Notable copy number losses of $17 \mathrm{p} 11.2$ and $11 \mathrm{q} 23.2$ were frequent; $17 \mathrm{p} 11.2$ loss was detected in 13 (54.2\%) of the cell lines and 19 (54.3\%) of the tissue specimens and 11q23.2 loss was detected in 15 (62.5\%) of the cell lines and $22(62.9 \%)$ of the tissue specimens (Table 1).

The clone-by-clone comparison of the DCNAs between the cell lines and the tumor tissues provided detailed information concerning the difference in DCNAs between two different sample groups. Gains of 5p14-p15, 20q11 and 20q13 and losses of 4p13-p16, 18q12, 18q21, Xq21.1 and Xq26-q28 were detected almost exclusively in the cell lines (Figure 3). For instance, the copy number gain of clones located on $20 \mathrm{q} 13.33$ and $20 \mathrm{q} 13.13$ were detected in as many as $75 \%$ of the cell lines, but it was a rare event (around 3\% of tumors) in the primary tumor tissues $\left(\mathrm{P}=5.68 \times 10^{-9}\right.$ and $\mathrm{P}=1.23 \times 10^{-8}$, respectively)(Table 2 ). The frequency of the Xq27.1 loss was detected in 16 (66.7\%) of the cell lines, but not detected in the tissue specimens $\left(\mathrm{P}=1.53 \times 10^{-8}\right)($ Table 2$)$.

The frequency of amplification was higher in the cell lines than in the tissue specimens (Table 3). DNA amplification was frequent at a wide chromosomal region 17q12-q21 in both the cell lines and tissue specimens, though other BAC clones with frequent DNA amplification were considerably different between these two sample groups (Table 3). The amplification of the chromosomal region 17q12 including ERBB2/HER2 was detected in $10(41.7 \%)$ of 24 cell lines and $6(17.1 \%)$ of 35 tissue specimens $(\mathrm{P}=0.037)$.

\section{Discussion}

Making a comparison of the CGH profiles between the established cell lines and their parental tumor tissue specimens is practically impossible, because the source tissue specimens are no longer obtainable. Therefore, the comparison of the genomic profiles obtained from cell lines with those from primary tumor tissues is one of the best ways to determine the difference in genomic aberrations between cell lines and primary tumor tissues and to identify recurrent cell lines-specific genomic aberrations.

The array-based CGH revealed a large number of DCNAs including recurrent ones in both breast cancer 


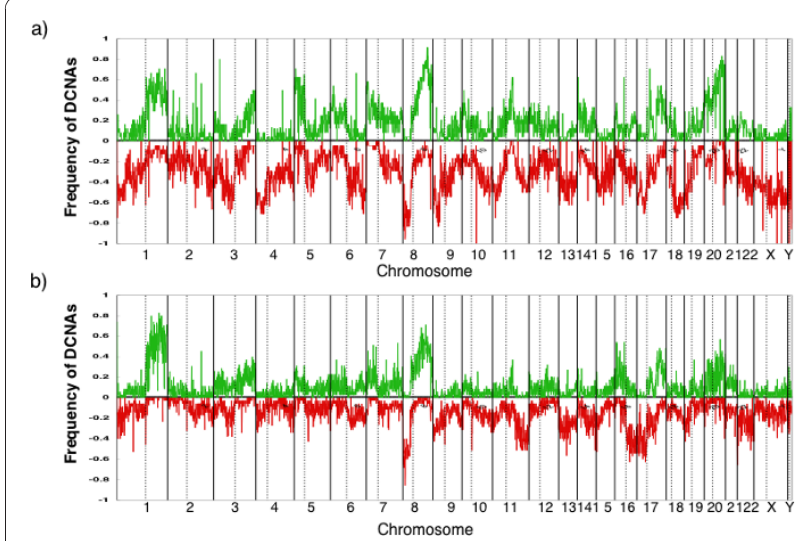

Figure 1 The frequency of DCNAs detected by array-based CGH in the breast cancer cell lines $(n=24)(a)$ and the primary breast cancer tissues $(\mathbf{n}=\mathbf{3 5})(\mathbf{b})$. Note the apparent similarity of the DCNA frequency pattern between two groups, gains of $1 q, 8 q$, $17 q$ and chromosome 20 and losses of $8 p, 11 q, 16 q$ and $17 p$ are frequent in both groups. However, the frequency of DCNA at each chromosomal region is different between these two groups, and other recurrent DCNAs are detected in the cell lines. Gains of $5 p$ and $20 q$ and losses of $4 p, 18 q$ and $X q$ are highly frequent in the cell lines in comparison to the tumor tissues. Green lines denote the frequency of DNA copy number gain in each BAC clone and red lines denote the frequency of DNA copy number loss in each BAC clone. Ordinate; frequency of DCNA for each BAC clone on the array, abscissa; chromosome number. cell lines and primary breast cancer tissues. There was a tendency that the average number of DCNAs was greater in cell lines than in primary breast cancer tissue specimens, 1832.4 (45.5\% of spots) and 972.2 clones (24.1\%) for a cell line and tumor tissue, respectively. This result is consistent with the data reported by Naylor and colleagues [24]. The comparison of CGH profiles between cell lines and tumor tissues revealed gains of $1 \mathrm{q}$ and $8 \mathrm{q}$ and losses of $8 \mathrm{p}, 11 \mathrm{q}, 16 \mathrm{q}$ and $17 \mathrm{p}$ as recurrent DCNAs shared by two groups. Although there are some variations in the CGH patterns of breast cancers between studies, copy number gains of 1q, 8q, 11q, $17 q$ and $20 q$ and losses of $6 q, 8 p, 9 p, 13 q, 16 q$ and $17 p$ were previously reported as recurrent aberrations in breast cancers [14,15,24-27]. Gains of 1q44,1q21 and 8q21-q23 and a loss of 17p11-p13 were detected in both of the cell lines and the tumor tissues at high rates ( $>50 \%$ of both samples). The present observations support the hypothesis that the cell lines basically preserve the genomic alterations that have occurred in primary tumor tissues [13,24]. These recurrent DCNAs detected in both cell lines and tumor tissues are though to be closely relevant to the development and progression of breast cancer. The clone-by-clone comparison of DNA copy numbers between cell lines and tumor tissues allowed detection of recurrent DCNAs exclusively in breast cancer cell lines as well as recurrent DCNAs

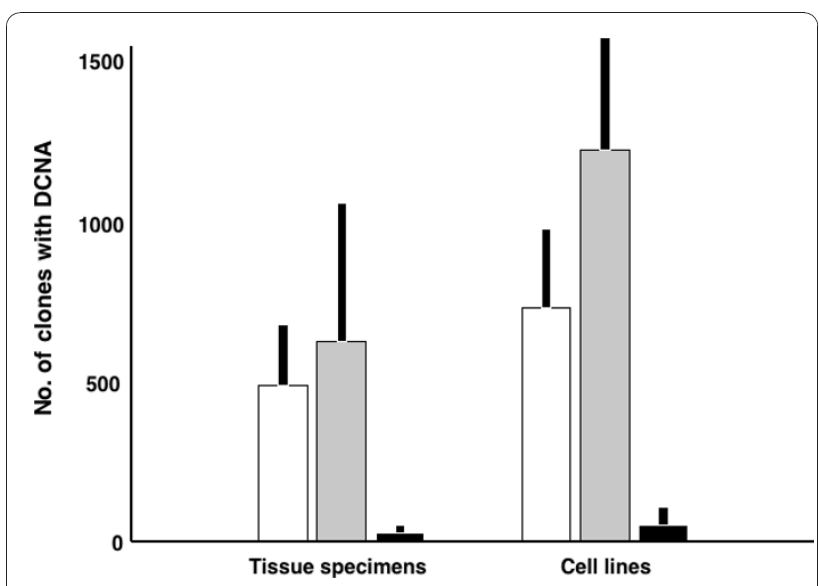

Figure 2 The average number of DNA copy number gain, loss and amplification for cell lines $(n=24)$ and the tumor tissues $(\mathbf{n}=\mathbf{3 5}$ ). The average number of clones with copy number gain is and $651.7 \pm 148.8$ and $424.2 \pm 215.9$ in the cell lines and tumor tissues, respectively. The average number of clones with copy number loss is $1180.7 \pm 433.8$ and $548.0 \pm 324.7$ in the cell lines and tumor tissues, respectively. The average number of amplification clones is $41.3 \pm 29.9$ and $15.9 \pm 18.6$ in the tumor tissues and the cell lines, respectively. The difference is statistically significant $(P=0.012)$. White columns; the average number of DNA copy number gain. Gray columns; the average number of DNA copy number loss. Black columns; the average number of amplifications. Black bars; standard deviations. Ordinate; frequency of DCNA for each BAC clone, abscissa; samples.

shared by two groups. Gains of 5p14-15, 20q11 and $20 \mathrm{q} 13$ and losses of 4p13-p16, 18q12, 18q21, Xq21.1 and Xq26-q28 were detected almost exclusively in the cell lines. Although the resolution of the BAC array used in this study is low in comparison to the tiling arrays, this study revealed a distinct difference in the patterns of the copy number aberrations between primary tumor tissues and cell lines. When data of cell lines are compared between the present CGH platform and others including tiling arrays, the chromosomal regions identified as copy number aberrations in this study are compatible with those provided by tiling arrays $[27,28]$. Indeed, gains of $8 \mathrm{q}$ and $20 \mathrm{q}$ were frequently detected by the $4 \mathrm{~K}$ array slides as well as by tiling arrays. The present data provided by the $4 \mathrm{~K}$ array platform are thus considered to be reliable.

It is particularly worth noting that some of recurrent DCNAs that are frequently detected in cell lines are hardly detected in primary cancer tissues. These DCNAs correspond to cell line-specific or in vitro-specific alterations $[13,24,29]$. Interestingly, these recurrent DCNAs identified in breast cancer cell lines were also detected in cell lines of other types, such as gastric cancer [30], lung cancer [31], colon cancer [32] and pancreatic cancer cell lines [33]. Established cell lines possibly carry the cell line-specific DCNAs regardless of the parental 
Table 1 Clones with significant difference in frequency of copy number changes between cell lines and tumor tissue specimens

\begin{tabular}{|c|c|c|c|c|}
\hline \multicolumn{5}{|c|}{ A: Clones with significant difference in frequency of copy number gain between cell lines and tumor tissue specimens } \\
\hline \multirow[t]{2}{*}{ Chromosomal region } & \multirow[t]{2}{*}{ Candidate genes } & \multicolumn{2}{|c|}{ Frequency (\%) } & \multirow[t]{2}{*}{ P-value } \\
\hline & & & Tissue & \\
\hline $20 q 13.33$ & ZGPAT, BTBD4, & $18 / 24$ & $1 / 35$ & $5.68551 \mathrm{E}-09$ \\
\hline $20 q 13.13$ & $\mathrm{COX} 6 \mathrm{CP} 2$ & $18 / 24$ & $1 / 33$ & $1.26370 \mathrm{E}-08$ \\
\hline $2 q 22.3$ & & $16 / 24$ & $0 / 34$ & $2.20899 \mathrm{E}-08$ \\
\hline $20 q 13.31$ & TFAP2C, PTMAP6 & $20 / 24$ & $6 / 35$ & 4.89015E-07 \\
\hline $7 p 22.3$ & FLJ20397, UNC84A, & $14 / 24$ & $1 / 35$ & $1.52990 \mathrm{E}-06$ \\
\hline $20 q 13.12$ & MYBL2 & $14 / 24$ & $1 / 35$ & $1.52990 \mathrm{E}-06$ \\
\hline $20 q 13.12$ & ADA, WISP2 & $14 / 24$ & $2 / 35$ & $7.97121 \mathrm{E}-06$ \\
\hline $20 q 11.21$ & DNMT3B, MAPRE1 & $11 / 24$ & $0 / 35$ & $8.97575 \mathrm{E}-06$ \\
\hline $20 q 11.21-20 q 11.22$ & SNTA1 & $11 / 24$ & $0 / 35$ & $8.97575 \mathrm{E}-06$ \\
\hline $8 q 24.3$ & HSF1, DGAT1, SCRT1 & $17 / 24$ & $5 / 35$ & $1.02265 \mathrm{E}-05$ \\
\hline $20 q 13.33$ & TPD52L2, DNAJC5 & $17 / 24$ & $5 / 35$ & $1.02265 \mathrm{E}-05$ \\
\hline $3 q 29$ & LRCH3, IQCG, & $12 / 24$ & $1 / 35$ & $1.77298 \mathrm{E}-05$ \\
\hline 20p13 & DEFB32, TRIB3 & $12 / 24$ & $1 / 35$ & $1.77298 \mathrm{E}-05$ \\
\hline $20 q 13.33$ & ARFGAP1, CHRNA4 & $19 / 24$ & $8 / 35$ & $2.00152 \mathrm{E}-05$ \\
\hline $5 p 14.1$ & & $13 / 24$ & $2 / 35$ & $2.68521 \mathrm{E}-05$ \\
\hline $11 q 13.3-11 q 13.4$ & PPFIA1, CTTN, SHANK2 & $13 / 24$ & $2 / 35$ & $2.68521 \mathrm{E}-05$ \\
\hline $20 q 11.21$ & BCL2L1, TPX2, MYLK2 & $13 / 24$ & $2 / 35$ & $2.68521 \mathrm{E}-05$ \\
\hline $20 q 13.33$ & KCNQ2, EEF1A2, PTK6, & $17 / 24$ & $6 / 35$ & $3.26970 \mathrm{E}-05$ \\
\hline $5 p 15.31$ & & $15 / 24$ & $4 / 35$ & $3.72069 \mathrm{E}-05$ \\
\hline $5 p 15.2$ & MARCH6 & $15 / 24$ & $4 / 35$ & $3.72069 \mathrm{E}-05$ \\
\hline $5 p 15.1$ & BASP1, FTHL10 & $15 / 24$ & $4 / 35$ & $3.72069 \mathrm{E}-05$ \\
\hline $6 \mathrm{q} 22.31$ & & $16 / 24$ & $4 / 31$ & $3.94622 \mathrm{E}-05$ \\
\hline $8 q 24.21$ & MYC, PVT1, & $22 / 24$ & $14 / 35$ & $6.40836 \mathrm{E}-05$ \\
\hline $7 q 11.23$ & POR, TMPIT, DUSP24 & $9 / 24$ & $0 / 35$ & 8.30527E-05 \\
\hline $14 q 22.2-14 q 22.3$ & GALIG, LGALS3 DLG7 & $9 / 24$ & $0 / 35$ & $8.30527 \mathrm{E}-05$ \\
\hline $19 q 13.43$ & ZNF544, ZNF8, HKR2 & $9 / 24$ & $0 / 35$ & 8.30527E-05 \\
\hline 20p11.23 & ZNF339, RPL15P1 & $9 / 24$ & $0 / 35$ & 8.30527E-05 \\
\hline $3 q 29$ & TMEM44, FLJ11301 & $12 / 24$ & $2 / 35$ & $8.56953 \mathrm{E}-05$ \\
\hline 10p15.3 & GTPBP4, IDI2, IDI1 & $12 / 24$ & $2 / 35$ & $8.56953 \mathrm{E}-05$ \\
\hline 20p13 & CSNK2A1 & $12 / 24$ & $2 / 35$ & $8.56953 \mathrm{E}-05$ \\
\hline $20 q 13.2$ & ZNF217 & $17 / 24$ & $7 / 35$ & $9.43882 \mathrm{E}-05$ \\
\hline
\end{tabular}

B: Clones with siginificant difference in frequecy of copy number loss between cell lines and tumor tissue specimens

\begin{tabular}{|c|c|c|c|c|}
\hline \multirow[t]{2}{*}{ Chromosomal region } & \multirow[t]{2}{*}{ Candidate genes } & \multicolumn{2}{|c|}{ Frrequency (\%) } & \multirow[t]{2}{*}{ P-value } \\
\hline & & Cell lines & Tissue & \\
\hline Xp11.3 & UTX & $21 / 24$ & $1 / 35$ & $3.98705 \mathrm{E}-11$ \\
\hline Xq27.1 & - & $16 / 24$ & $0 / 35$ & 1.52947E-08 \\
\hline Xq21.1 & - & $18 / 24$ & $2 / 35$ & $3.33574 \mathrm{E}-08$ \\
\hline $4 p 15.1$ & - & $16 / 24$ & $1 / 35$ & $1.05951 \mathrm{E}-07$ \\
\hline $4 p 13$ & - & $14 / 24$ & $0 / 34$ & $3.16890 \mathrm{E}-07$ \\
\hline $18 q 12.3$ & RIT2 & $16 / 23$ & $2 / 34$ & $3.88478 \mathrm{E}-07$ \\
\hline Xq26.2 & OR2AF1 & $15 / 24$ & $1 / 35$ & 4.14685E-07 \\
\hline$X q 27.3$ & HCP44 & $15 / 24$ & $1 / 35$ & 4.14685E-07 \\
\hline $18 q 21.1$ & MAPK4 & $18 / 24$ & $4 / 35$ & 7.03535E-07 \\
\hline Xq28 & F8, VBP1, RAB39B, CLIC2 PHF10P1 & $13 / 24$ & $0 / 35$ & 8.17519E-07 \\
\hline $18 q 21.1$ & KIAA0427 & $17 / 24$ & $3 / 34$ & $9.90978 \mathrm{E}-07$ \\
\hline 8p12 & WRN & $18 / 24$ & $4 / 34$ & $1.01721 \mathrm{E}-06$ \\
\hline $2 q 34$ & SPAG16 & $13 / 24$ & $0 / 34$ & $1.10437 \mathrm{E}-06$ \\
\hline$X q 26.2$ & GPC3 & $14 / 24$ & $1 / 35$ & $1.52990 \mathrm{E}-06$ \\
\hline
\end{tabular}


Table 1: Clones with significant difference in frequency of copy number changes between cell lines and tumor tissue specimens (Continued)

\begin{tabular}{|c|c|c|c|c|}
\hline $4 p 16.3$ & FLJ35816 & $15 / 24$ & $2 / 35$ & $2.23384 \mathrm{E}-06$ \\
\hline 4p15.1 & - & $15 / 24$ & $2 / 35$ & $2.23384 \mathrm{E}-06$ \\
\hline $18 q 12.2$ & - & $15 / 24$ & $2 / 35$ & $2.23384 \mathrm{E}-06$ \\
\hline Xq28 & SLC14A2, SLC14A1 & $15 / 24$ & $2 / 35$ & $2.23384 \mathrm{E}-06$ \\
\hline $18 \mathrm{q} 21.1$ & KIAA0427 & $17 / 24$ & $3 / 34$ & $9.90978 \mathrm{E}-07$ \\
\hline $8 p 12$ & WRN & $18 / 24$ & $4 / 34$ & $1.01721 \mathrm{E}-06$ \\
\hline $2 q 34$ & SPAG16 & $13 / 24$ & $0 / 34$ & 1.10437E-06 \\
\hline$X q 26.2$ & GPC3 & $14 / 24$ & $1 / 35$ & $1.52990 \mathrm{E}-06$ \\
\hline $4 p 16.3$ & FLJ35816 & $15 / 24$ & $2 / 35$ & $2.23384 \mathrm{E}-06$ \\
\hline 4p15.1 & - & $15 / 24$ & $2 / 35$ & $2.23384 \mathrm{E}-06$ \\
\hline $18 q 12.2$ & - & $15 / 24$ & $2 / 35$ & $2.23384 \mathrm{E}-06$ \\
\hline $18 q 12.3$ & SLC14A2, SLC14A1 & $15 / 24$ & $2 / 35$ & $2.23384 \mathrm{E}-06$ \\
\hline 4p15.1 & - & $17 / 24$ & $4 / 34$ & $4.02576 \mathrm{E}-06$ \\
\hline $18 q 21.32$ & - & $17 / 24$ & $4 / 34$ & $4.02576 \mathrm{E}-06$ \\
\hline Xq28 & CSAG2, MAGEA2B MAGEA12, CSAG1 & $14 / 23$ & $2 / 35$ & $4.27750 \mathrm{E}-06$ \\
\hline $4 q 13.1$ & EPHA5 & $8 / 16$ & $0 / 35$ & 5.21729E-06 \\
\hline 3p22.1 & NKTR, ZNF651, KBTBD5 & $13 / 24$ & $1 / 35$ & $5.34274 \mathrm{E}-06$ \\
\hline $4 p 16.3$ & $\mathrm{HD}$ & $13 / 24$ & $1 / 35$ & $5.34274 \mathrm{E}-06$ \\
\hline $4 p 13$ & - & $13 / 24$ & $1 / 35$ & $5.34274 \mathrm{E}-06$ \\
\hline $4 q 22.1$ & - & $13 / 24$ & $1 / 35$ & $5.34274 \mathrm{E}-06$ \\
\hline $5 q 14.3$ & - & $13 / 24$ & $1 / 35$ & $5.34274 \mathrm{E}-06$ \\
\hline $18 q 12.1$ & - & $13 / 24$ & $1 / 35$ & $5.34274 \mathrm{E}-06$ \\
\hline
\end{tabular}

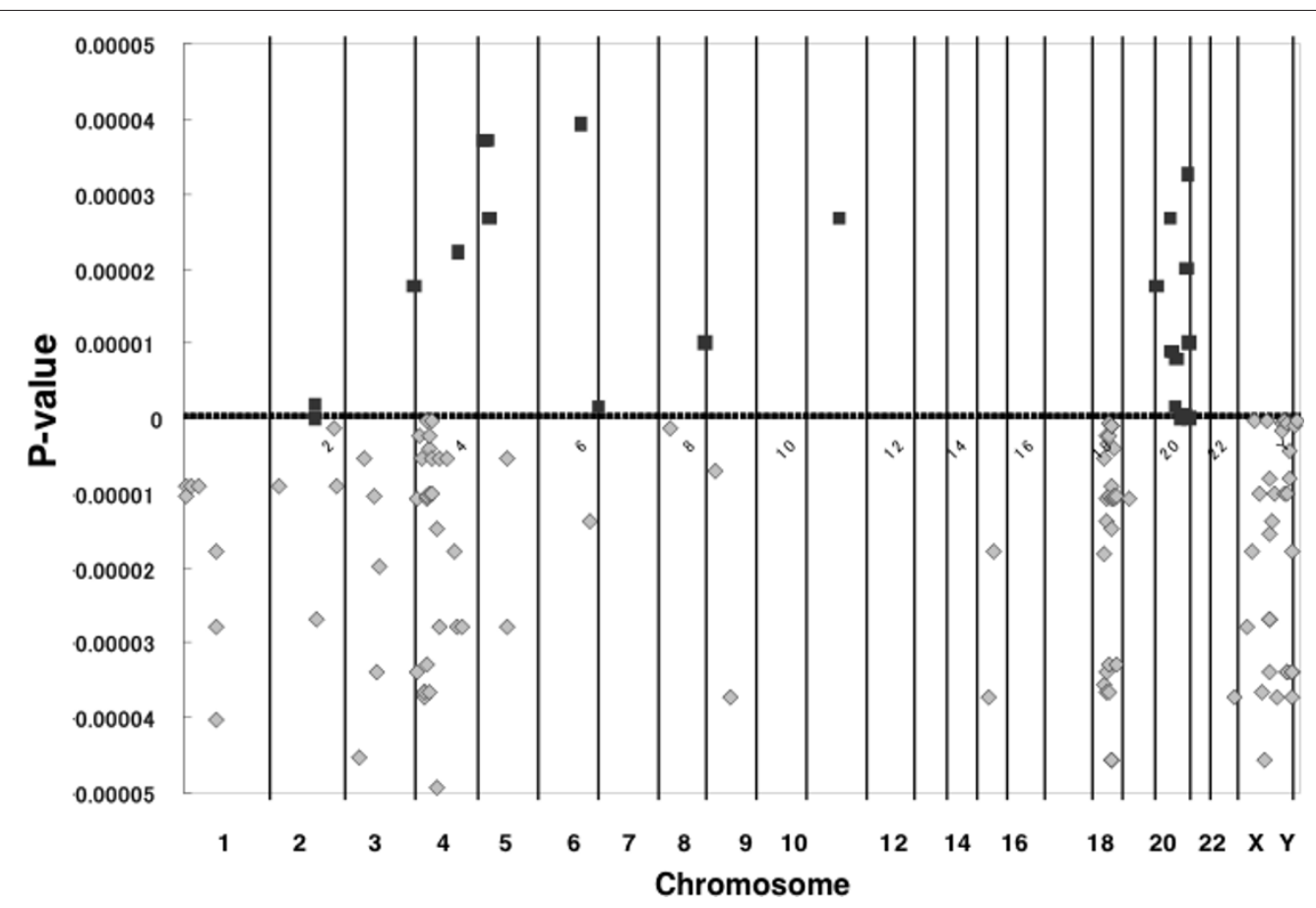

Figure 3 P-values and chromosomal regions with significant difference in the frequency of DNA copy number gains (black square in upper part) and losses (gray diamond in lower part). Clones with cell line-specific copy number gains are densely found at $20 \mathrm{q} 11$ and 20q13, whereas clones with cell line-specific losses are detected at 4p13-14, 18q12, 18q21, Xq21 and Xq26-28. This figure shows clones with highly significant difference $(p<0.00005)$ in the frequency between the cell lines and the tumor tissues. Ordinate; statistic P-values, abscissa; chromosome number. 
Table 2 Clones with recurrent copy number changes shared by cell lines and tissue specimens

\begin{tabular}{|c|c|c|c|c|}
\hline \multicolumn{5}{|c|}{ A: Clones with recurrent copy number gains shared by cell lines and tissue specimens } \\
\hline \multirow[t]{2}{*}{ Chromosomal region } & \multirow[t]{2}{*}{ Genes } & \multicolumn{2}{|c|}{ Frequency } & \multirow[t]{2}{*}{ P-value } \\
\hline & & Cell lines & Tissue & \\
\hline $1 q 44$ & FLJ10157 & $13 / 24$ & $19 / 35$ & 0.992806112 \\
\hline $8 q 22.1$ & TSPYL5 & $15 / 24$ & $22 / 35$ & 0.977767962 \\
\hline $8 q 21.3$ & NBS1, DECR1 & $14 / 24$ & 20/35 & 0.927569885 \\
\hline $8 q 23.1$ & MGC35555 & $14 / 24$ & $20 / 35$ & 0.927569885 \\
\hline $1 q 21.1$ & - & $12 / 24$ & $18 / 35$ & 0.914136773 \\
\hline $1 q 21.2-1 q 21.3$ & PIP5K1A, PSMD4, KIAA1441 & $12 / 24$ & $18 / 35$ & 0.914136773 \\
\hline $1 q 23.1$ & SH2D2A, INSRR, NTRK1 & $12 / 24$ & $18 / 35$ & 0.914136773 \\
\hline $1 \mathrm{q} 32.1$ & MDM4 & $12 / 24$ & $18 / 35$ & 0.914136773 \\
\hline $1 q 42.11$ & CAPN2, TP53BP2 & $12 / 24$ & $17 / 35$ & 0.914136773 \\
\hline $1 q 44$ & FLJ32001, CGI-49 & $12 / 24$ & $17 / 35$ & 0.914136773 \\
\hline $1 q 44$ & OR1C1, OR9H1P, OR11L1 & $12 / 24$ & $18 / 35$ & 0.914136773 \\
\hline $7 p 14.1$ & TRGJP2, TRGC1，TRGJ1 & $12 / 24$ & $18 / 35$ & 0.914136773 \\
\hline 7p14.1 & TRGJP1, TRGV11, TRGVB & $12 / 24$ & $17 / 35$ & 0.914136773 \\
\hline $8 q 24.22$ & - & $12 / 24$ & $17 / 35$ & 0.914136773 \\
\hline $17 q 25.3$ & $\mathrm{TBCD}$ & $12 / 24$ & $17 / 35$ & 0.914136773 \\
\hline $1 q 25.1$ & TNN, KIAA0040 & $14 / 24$ & $21 / 35$ & 0.898133861 \\
\hline $8 q 21.3$ & NBS1 & $14 / 24$ & $18 / 35$ & 0.898133861 \\
\hline $8 q 22.2$ & KCNS2, STK3 & $14 / 24$ & $18 / 35$ & 0.898133861 \\
\hline \multicolumn{5}{|c|}{ B; Clones with recurrent copy number losses shared by cell lines and tissue specimens } \\
\hline \multirow[t]{2}{*}{ Chromosomal region } & Genes & \multicolumn{2}{|c|}{ Frequency (\%) } & P-value \\
\hline & & Cell lines & Tissue & \\
\hline 17p11.2 & DRG2, MYO15A, LLGL1, FLII & $13 / 24$ & $19 / 35$ & 0.992806112 \\
\hline $17 \mathrm{p} 12$ & LOC388338, HS3ST3B1 & $15 / 24$ & $22 / 35$ & 0.977767962 \\
\hline $11 q 23.2$ & ZBTB16 & $12 / 24$ & $18 / 35$ & 0.914136773 \\
\hline $11 q 25$ & SPAS1 & $' 12 / 24$ & $18 / 35$ & 0.914136773 \\
\hline 17p13.3 & NXN & $' 12 / 24$ & $17 / 35$ & 0.914136773 \\
\hline 17p13.1 & ASGR1, DLG4, ACADVL & $14 / 24$ & $21 / 35$ & 0.898133861 \\
\hline 17p13.1 & MYH3, SCO1, MDS006 & $14 / 24$ & $19 / 34$ & 0.852726956 \\
\hline
\end{tabular}

tumor types. DCNA profiles primarily depend on organs and tissues from which cancer develops [13,34,35]. Breast epithelial cells transformed in vitro show genomic alterations similar to those of cell lines [36]. Therefore, taking these observations into consideration, it is legitimate to consider that in vitro environments endow cells with genomic aberrations of which cell line-specific DCNAs are critical for cells to survive and proliferate in vitro. Indeed, it is known that the pattern of $\mathrm{CGH}$ profiles change in varying degree with the cell passage numbers [9].

The difference in the $\mathrm{CGH}$ profiles found between the cell lines and tumor tissues is not attributed to just variations in genomic alterations between parental histological types, because DCNAs detected exclusively in cell lines are not explained by the difference in histologic types [37-39]. Accordingly, this also strengthens the view that recurrent DCNAs detected exclusively in cell lines can be called cell line-specific aberrations.
The average number of amplified clones was more than double in the cell lines than the tumor tissues (41.3 vs. 15.9). In particular, the frequency of amplification for clones on 17q12-q21, encompassing many genes including ERBB2/HER2 that is the most frequent amplified gene in breast cancers [40,41], was higher in the cell lines than in tissue specimens. The amplification frequency of the BAC clone harboring ERBB2/HER2 was in $41.7 \%$ of the cell lines and $17.1 \%$ of the tumor tissues. The amplification of ERBB2/HER2 is usually detected in no more than $20 \%$ of breast cancer patient [42]. Therefore, it can be said that additional DNA amplifications occur not only in the chromosomal region but also in other regions in the cell lines.

\section{Conclusions}

The cell lines carry the cell lines-specific DCNAs together with in vivo alterations. Cell line-specific DCNAs were as follows: gains of 5p14-15, 20q11 and 
Table 3 Clones with frequent DNA amplification in breast cancer cell lines and primary tumor tissues

\begin{tabular}{|c|c|c|c|}
\hline Chromosomal region & Candidate genes & No, of tumors & Frequency (\%) \\
\hline \multicolumn{4}{|l|}{ Cell lines $(n=24)$} \\
\hline $17 q 12$ & NEUROD2, PPP1R1B, STARD3, TCAP, PNMT, PERLD1 & 10 & 41.7 \\
\hline $17 q 12$ & PERLD1, ERBB2, GRB7, ZNFN1A3 & 10 & 41.7 \\
\hline $17 q 21.1$ & ZNFN1A3, ZPBP2, GSDML, ORMDL3, GSDM1, PSMD3 & 8 & 33.3 \\
\hline $8 q 24.13$ & $\mathrm{ZHX} 2$ & 7 & 29.2 \\
\hline $5 p 15.33$ & TPPP, LOC442127, ZDHHC11 & 6 & 25.0 \\
\hline $8 q 24.12$ & SAMD12 & 6 & 25.0 \\
\hline $8 q 24.12$ & MRPL13, MTBP, SNTB1 & 6 & 20.5 \\
\hline $8 q 24.22$ & $\mathrm{TG}$ & 6 & 25.0 \\
\hline $20 q 13.2$ & BCAS1, CYP24A1 & 6 & 25.0 \\
\hline $20 q 13.2$ & BCAS1 & 6 & 25.0 \\
\hline $20 q 13.2$ & DOK5 & 6 & 25.0 \\
\hline $20 q 13.2$ & DOK5 & 6 & 25.0 \\
\hline $20 q 13.32$ & PCK1, ZBP1, TMEPAI, & 6 & 25.0 \\
\hline \multicolumn{4}{|l|}{ Tumor tissues $(n=35)$} \\
\hline $17 q 12$ & NEUROD2, PPP1R1B, STARD3, TCAP, PNMT, PERLD1 & 7 & 20.0 \\
\hline $17 q 12$ & PERLD1, ERBB2, GRB7, ZNFN1A3 & 8 & 17.1 \\
\hline $17 q 21.1$ & ZNFN1A3, ZPBP2, GSDML, ORMDL3, GSDM1, PSMD3 & 6 & 17.7 \\
\hline $8 p 12$ & - & 5 & 14.3 \\
\hline $8 q 21.11$ & PI15 & 5 & 14.3 \\
\hline $8 q 21.11$ & $\mathrm{ZFHX} 4$ & 5 & 14.3 \\
\hline $8 q 24.21$ & DDEF1 & 5 & 14.3 \\
\hline $17 q 23.3$ & TEX2 & 5 & 14.3 \\
\hline $8 p 12$ & WHSC1L1, LETM2, FGFR1 & 4 & 11.4 \\
\hline 8p12-8p11.23 & LETM2, FGFR1 & 4 & 11.4 \\
\hline $8 p 11.23$ & TACC1, PLEKHA2 & 4 & 11.4 \\
\hline $8 q 21.11$ & - & 4 & 11.4 \\
\hline $8 q 21.12$ & IL7 & 4 & 11.4 \\
\hline $8 q 21.3$ & RUNX1T1 & 4 & 11.4 \\
\hline $8 q 22.1$ & - & 4 & 11.4 \\
\hline $8 q 22.3$ & - & 4 & 11.4 \\
\hline $8 q 23.3$ & - & 4 & 11.4 \\
\hline $8 q 24.11$ & - & 4 & 11.4 \\
\hline $8 q 24.13$ & - & 4 & 11.4 \\
\hline $17 q 23.3$ & CSH1, CSHL1, GH1, CD79B, SCN4A & 4 & 11.4 \\
\hline
\end{tabular}

-: The relevant clone harbors no genes identified.

The number of clones with DNA amplification that is detected in more than $10 \%$ of samples is 101 clones in the cell lines, while it is only 20 clones in tumor tissues.

$20 \mathrm{q} 13$ and losses of 4p13-p16, 18q12, 18q21, Xq21.1 and Xq26-q28. When cell lines are used as an alternative to primary tumor tissues, it is therefore important to keep in mind that cell lines do not always represent genotypes of parental tumor tissue specimens.

\section{Abbreviations}

CGH: comparative genomic hybridization; DCNAs: DNA copy number aberrations; BAC: bacterial artificial chromosome

\section{Acknowledgements}

This work was supported in part by The Ministry of Education, Culture of Japan (19390102 and 20659055) and The New Energy and Industrial
Technology Development Organization (NEDO) of Japan. We acknowledge Takae Okada for programming assistance.

CGH data are available at the following website: http://cibex.nig.ac.jp/cibex2/ ExperimentMiame.do?queryExperimentalDesignAccession=CBX105

\section{Author details}

'Department of Pathology, Yamaguchi University Graduate School of Medicine, Ube 755-8505, Japan. ${ }^{2}$ Applied Gene Technology Research Group, Research Institute for Cell Engineering, National Institute of Advanced Industrial Science and Technology, Tsukuba-shi 305-8566, Japan.

${ }^{3}$ Department of Surgery, Yamaguchi University Graduate School of Medicine, Ube 755-8505, Japan.

\section{Authors' contributions}

KT, SK and TM carried out array CGH of tumor tissues, SS and TH were invovled in array CGH of cell lines, SY and MO gathered tumor tissue 
specimens and clinico-pathological data, MN analyzed array CGH data. KT and SK organized the array CGH data, and KT drafted the manuscript. KS conceived of this study, and participated in its design and coordination. All authors read and approved the final manuscript.

\section{Competing interests}

The authors declare that they have no competing interests.

Received: 7 February 2009

Accepted: 14 January 2010 Published: 14 January 2010

\section{References}

1. Olsavsky KM, Page JL, Johnson MC, Zarbl H, Strom SC, Omiecinski CJ: Gene expression profiling and differentiation assessment in primary human hepatocyte cultures, established hepatoma cell lines, and human liver tissues. Toxicol Appl Pharmacol 2007, 222:42-56.

2. Montel V, Huang TY, Mose E, Pestonjamasp K, Tarin D: Expression profiling of primary tumors and matched lymphatic and lung metastases in a xenogeneic breast cancer model. Am J Pathol 2005, 166:1565-79.

3. Sandberg R, Ernberg I: The molecular portrait of in vitro growth by metaanalysis of gene-expression profiles. Genome Biol 2005, 6:R65.

4. Li A, Walling J, Kotliarov Y, Center A, Steed ME, Ahn SJ, Rosenblum M, Mikkelsen T, Zenklusen JC, Fine HA: Genomic changes and gene expression profiles reveal that established glioma cell lines are poorly representative of primary human gliomas. Mol Cancer Res 2008, 6:21-30.

5. Ried T, Heselmeyer-Haddad K, Blegen H, Schröck E, Auer G: Genomic changes defining the genesis, progression, and malignancy potential in solid human tumors: a phenotype/genotype correlation. Genes Chromosomes Cancer 1999, 25:195-204.

6. Baak JP, Path FR, Hermsen MA, Meijer G, Schmidt J, Janssen EA: Genomics and proteomics in cancer. Eur J Cancer 2003, 39:1199-215.

7. Bergamaschi A, Kim YH, Wang P, Sørlie T, Hernandez-Boussard T, Lonning PE, Tibshirani R, Børresen-Dale AL, Pollack JR: Distinct patterns of DNA copy number alteration are associated with different clinicopathological features and gene-expression subtypes of breast cancer. Genes Chromosomes Cancer 2006, 45:1033-40.

8. Lai LA, Paulson TG, Li X, Sanchez CA, Maley C, Odze RD, Reid BJ, Rabinovitch PS: Increasing genomic instability during premalignant neoplastic progression revealed through high resolution array-CGH. Genes Chromosomes Cancer 2007, 46:532-42.

9. Wenger SL, Senft JR, Sargent LM, Bamezai R, Bairwa N, Grant SG: Comparison of established cell lines at different passages by karyotype and comparative genomic hybridization. Biosci Rep 2004, 24:631-9.

10. Polianskaya GG, Vakhtin luB: The karyotypic structure of cell populations in vitro as an integral system. Tsitologiia 2003, 45:115-31.

11. Mamaeva SE: Karyotypic evolution of cells in culture: a new concept. Int Rev Cytol 1998, 178:1-40.

12. Cuthill S, Agarwal P, Sarkar S, Savelieva E, Reznikoff CA: Dominant genetic alterations in immortalization: role for $20 \mathrm{q}$ gain. Genes Chromosomes Cancer 1999, 26:304-11.

13. Greshock J, Nathanson K, Martin AM, Zhang L, Coukos G, Weber BL, Zaks TZ: Cancer cell lines as genetic models of their parent histology: analyses based on array comparative genomic hybridization. Cancer Res 2007, 67:3594-600

14. Garcia MJ, Pole JC, Chin SF, Teschendorff A, Naderi A, Ozdag H, Vias M, Kranjac T, Subkhankulova T, Paish C, Ellis I, Brenton JD, Edwards PA, Caldas C: A $1 \mathrm{Mb}$ minimal amplicon at 8p11-12 in breast cancer identifies new candidate oncogenes. Oncogene 2005, 24:5235-45.

15. Neve RM, Chin K, Fridlyand J, Yeh J, Baehner FL, Fevr T, Clark L, Bayani N, Coppe JP, Tong F, Speed T, Spellman PT, DeVries S, Lapuk A, Wang NJ, Kuo WL, Stilwell JL, Pinkel D, Albertson DG, Waldman FM, McCormick F, Dickson RB, Johnson MD, Lippman M, Ethier S, Gazdar A, Gray JW: A collection of breast cancer cell lines for the study of functionally distinct cancer subtypes. Cancer Cell 2006, 10:515-27.

16. Hashimoto Y, Oga A, Okami K, Imate Y, Yamashita Y, Sasaki K: Relationship between cytogenetic aberrations by $\mathrm{CGH}$ coupled with tissue microdissection and DNA ploidy by laser scanning cytometry in head and neck squamous cell carcinoma. Cytometry 2000, 40:161-166.

17. Noutomi Y, Ita M, Okafuji M, Uchida K, Kawauchi S, Oga A, Furuya T, Ueyama Y, Sasaki K: Comparative genomic hybridization reveals genetic progression of oral squamous cell carcinoma from dysplasia via two different tumorigenetic pathways. J Pathol 2006, 210:67-74.

18. Hashimoto K, Mori N, Tamesa T, Okada T, Kawauchi S, Oga A, Furuya T, Tangoku A, Oka M, Sasaki K: Analysis of DNA copy number aberrations in hepatitis $C$ virus-associated hepatocellular carcinomas by conventional CGH and array CGH. Mod Pathol 2004, 17:617-22.

19. Yamamoto $Y$, Chochi $Y$, Matsuyama H, Eguchi S, Kawauchi S, Furuya T, Oga A, Kang JJ, Naito K, Sasaki K: Gain of 5p15.33 is associated with progression of bladder cancer. Oncology 2007, 72:132-138.

20. Chochi Y, Kawauchi S, Nakao M, Furuya T, Hashimoto K, Oga A, Oka M, Sasaki K: A copy number gain of the $6 \mathrm{p}$ arm is linked with advanced hepatocellular carcinoma. J Pathol 2009, 217:677-84.

21. Furuya T, Uchiyama T, Adachi A, Okada T, Nakao M, Oga A, Kawauchi S, Kang JJ, Yang S-J, Sasaki K: The development of a mini-array for estimating the disease states of gastric adenocarcinoma by array $\mathrm{CGH}$. BMC Cancer 2008, 8:393.

22. Nakao M, Kawauch S, Furuya T, Uchiyama T, Adachi J, Okada T, Ikemoto K, Oga A, Sasaki K: Identification of chromosomal regions with DNA copy number aberrations associated with node metastasis of colorectal adenocarcinomas based on the array CGH profiles. Cancer Genet Cytogenet 2009, 181:70-76.

23. Saito S, Morita K, Hirano T: High frequency of common DNA copy number abnormalities detected by bacterial artificial chromosome array comparative genomic hybridization in 24 breast cancer cell lines. Hum Cell 2009, 22:1-10.

24. Naylor TL, Greshock J, Wang Y, Colligon T, Yu QC, Clemmer V, Zaks TZ, Weber BL: High resolution genomic analysis of sporadic breast cancer using array-based comparative genomic hybridization. Breast Cancer Res 2005, 7:R1186-98.

25. Knuutila S, Autio K, Aalto Y: Online access to CGH data of DNA sequence copy number changes. Am J Pathol 2000, 157:689-690.

26. Rennstam K, Ahlstedt-Soini M, Baldetorp B, Bendahl PO, Borg A, Karhu R, Tanner M, Tirkkonen M, Isola J: Patterns of chromosomal imbalances defines subgroups of breast cancer with distinct clinical features and prognosis. A study of 305 tumors by comparative genomic hybridization. Cancer Res 2003, 63:8861-8.

27. Shadeo A, Lam WL: Comprehensive copy number profiles of breast cancer cell model genomes. Breast Cancer Res 2006, 8:R9.

28. Mackay A, Tamber N, Fenwick K, Iravani M, Grigoriadis A, Dexter T, Lord CJ, Reis-Filho JS, Ashworth A: A high-resolution integrated analysis of genetic and expression profiles of breast cancer cell lines. Breast Cancer Res Treat 2009, 118:481-98.

29. Ratsch SB, Gao Q, Srinivasan S, Wazer DE, Band V: Multiple genetic changes are required for efficient immortalization of different subtypes of normal human mammary epithelial cells. Radiat Res 2001, 155:143-50.

30. Takada H, Imoto I, Tsuda H, Sonoda I, Ichikura T, Mochizuki H, Okanoue T, Inazawa J: Screening of DNA copy-number aberrations in gastric cancer cell lines by array-based comparative genomic hybridization. Cancer Sci 2005, 96:100-10.

31. Garnis C, Lockwood WW, Vucic E, Ge Y, Girard L, Minna JD, Gazdar AF, Lam S, MacAulay C, Lam WL: High resolution analysis of non-small cell lung cancer cell lines by whole genome tiling path array $\mathrm{CGH}$. Int $J$ Cancer 2006, 118:1556-64.

32. Kleivi K, Teixeira MR, Eknaes M, Diep CB, Jakobsen KS, Hamelin R, Lothe RA: Genome signatures of colon carcinoma cell lines. Cancer Genet Cytogenet 2004, 155:119-31.

33. Gysin S, Rickert P, Kastury K, McMahon M: Analysis of genomic DNA alterations and mRNA expression patterns in a panel of human pancreatic cancer cell lines. Genes Chromosomes Cancer 2005, 44:37-51.

34. Oga A, Kawauchi S, Izumi H, Ping LX, Furuya T, Sasaki K: New perspectives for tumor pathology provided by comparative genomic hybridization. Int J Clin Oncol 2002, 7:133-7.

35. Kallioniemi A: CGH microarrays and cancer. Curr Opin Biotechnol 2008, 19:36-40.

36. Balogh GA, Russo $H_{H}$, Balsara BR, Russo J: Detection of chromosomal aberrations by comparative genomic hybridization during transformation of human breast epithelial cells in vitro. Int J Oncol 2006, 29:877-81.

37. Nishizaki T, Chew K, Chu L, Isola J, Kallioniemi A, Weidner N, Waldman FM: Genetic alterations in lobular breast cancer by comparative genomic hybridization. Int J Cancer 1997, 74:513-7. 
38. Richard F, Pacyna-Gengelbach M, Schlüns K, Fleige B, Winzer KJ, Szymas J, Dietel M, Petersen I, Schwendel A: Patterns of chromosomal imbalances in invasive breast cancer. Int I Cancer 2000, 89:305-10.

39. Günther K, Merkelbach-Bruse S, Amo-Takyi BK, Handt S, Schröder W, Tietze L: Differences in genetic alterations between primary lobular and ductal breast cancers detected by comparative genomic hybridization. J Pathol 2001, 193:40-7.

40. Kauraniemi P, Kuukasjarvi T, Sauter G, Kallioniemi A: Amplification of a 280kilobase core region at the ERBB2 locus leads to activation of two hypothetical proteins in breast cancer. Am J Pathol 2003, 163:1979-1984.

41. Willis S, Hutchins AM, Hammet F, Ciciulla J, Soo WK, White D, van der SP, Henderson MA, Gish K, Venter DJ, Armes JE: Detailed gene copy number and RNA expression analysis of the 17q12-23 region in primary breast cancers. Genes Chromosomes Cancer 2003, 36:382-392.

42. Pal SK, Pegram M: HER2 targeted therapy in breast cancer...beyond Herceptin. Rev Endocr Metab Disord 2007, 8:269-77.

\section{Pre-publication history}

The pre-publication history for this paper can be accessed here:http://www. biomedcentral.com/1471-2407/10/15/prepub

doi:10.1186/1471-2407-10-15

Cite this article as: Tsuji et al:: Breast cancer cell lines carry cell linespecific genomic alterations that are distinct from aberrations in breast cancer tissues: Comparison of the CGH profiles between cancer cell lines and primary cancer tissues. BMC Cancer 2010 10:15.

\section{Submit your next manuscript to BioMed Central} and take full advantage of:

- Convenient online submission

- Thorough peer review

- No space constraints or color figure charges

- Immediate publication on acceptance

- Inclusion in PubMed, CAS, Scopus and Google Scholar

- Research which is freely available for redistribution

Submit your manuscript at www.biomedcentral.com/submit 